\title{
The Psychic Subject Constitution in the Freudian Theory
}

\author{
Henrique Guilherme Scatolin \\ PUC-SP (Pontificate Catholic University of São Paulo), São Paulo, Brazil
}

\begin{abstract}
From a singular reading on Freudian metapsychology, this paper aims to carry out a bibliographic review on the male subject psychic constitution, pointing out the main concepts developed by Freud for his understanding. In order to achieve such result, this paper departs from the satisfaction experience, highlighting the parents' desire for this child while being a singular subject, passing by the impulse, narcissism, and self-eroticism concepts. Parallel to these concepts development, a child pre-genital and genital organizations reading is made, focusing on the Oedipus complex interlacing with the castration complex, noting the effect of repression on infantile sexuality; as well as the superego formation and the possible identifications after the Oedipal complex dissolution. It is concluded that, for the Freudian psychoanalysis, it is imperative to relieve the articulation between the castration complex and Oedipus complex to understand the psychic destinations of each subject.
\end{abstract}

Keywords: male psychic constitution, satisfaction experience, infant genital organization

\section{Introduction}

This paper aims to address the subject psychic constitution according to the Freudian theory. For this purpose, it is necessary to go through the Viennese master early studies on the psychic constitution.

At the end of the 19th century, the time corresponding to the start of psychoanalytic theory pillars, Freud is at the beginning of his study on the psychic subject constitution. When writing the letter No. 24 to Fliess, Freud (1986/1996) notes:

After periods of ten to eleven hours with the neurosis... I am tormented by two objectives; examine what form the mental functioning theory will assume... and, secondly, extract from psychopathology a profit for the normal psychology. Actually, it is impossible to have a satisfactory general conception of neuropsychotic disorders if you cannot link it to clear assumptions about the normal mental processes. (p. 130)

So, in 1895, Freud is in the early days of the studies on the neurotic and normal processes. That same year, he focuses, on the text "Project for a Scientific Psychology", the importance of another presence, usually the mother, at the beginning of the baby's life, for his psychic development.

According to Freud, in the psychic apparatus origin, the tension state present in the baby body, generated by the hungry tries to be released by means of a motor discharge, such as screaming and crying; but no motor discharge leads to a result for relieving his internal tension. The newborn body is incapable of a "specific action" that extinguishes the tension state, needing the help from another person. That is, of a "foreign help", from his mother (or from a substitute) through a specific action. In this way, the "satisfaction experience" puts an end to the child internal tension through the mother (or substitute) external aid to her son, having this experience the more radical implications in the development of an individual function.

Henrique Guilherme Scatolin, Master, PUC-SP (Pontificate Catholic University of São Paulo). 
Freud resumes the satisfaction experience importance in the psychic constitution in the chapter VII of the book The Dreams Interpretation. In this famous book, Freud highlights that the "satisfaction experience" introduces the desire in the baby, conceiving the desire as "a psychic motion which will seek to recatechize the perception mnemonic image and retrace the own perception, that is, to re-establish the original satisfaction situation" (1900/1996, p. 595). He postulates that only desire is capable of putting the psychic apparatus in motion, in accordance with the principle of pleasure. Thus, in the psychic constitution first moments, when the internal tension state created by the need arises again, the satisfactory object image is reinvested as the desire hallucinatory satisfaction.

But when publishing the text "Formulations the Two Principles of Mental Functioning", Freud (1911/199) points out:

It will be objected that an organization that was slave of the pleasure principle and disregarded the external world reality could not keep alive, even for a shorter time... The use of a fiction like this, however, is justified when one considers the baby—-provided that it contains the care received from the mother—almost performing a psychic system of this kind. (p. 238)

Freud, in this quotation, is referring to the reality principle introduction in the baby psychic constitution at the first moments. So, after the satisfaction experience, as there is an increasing requirement of internal needs and, consequently, an absence of expected satisfaction, the child abandons this satisfaction attempt through the hallucination. And due to the lack of satisfaction through the hallucination, a new principle of mental functioning is started: the reality principle.

After the first satisfaction experience that establishes the desire in the child, the Viennese master stresses the newborn maternal cares importance. In 1905, in the Three Essays on Sexuality Theory, he reiterates the importance assigned to the other, who usually is the maternal figure, in the child sexuality establishment. Thus, Freud (1905/1996) states that:

The child deal with the person who assists is, for him, a constant source of excitement and sexual satisfaction from erogenous zones, and even more if this person, usually the mother, admires the child with the feelings derived from her own sexual life: She touches, kisses and cradles, and it is perfectly clear that she treats him as the replacement of a fully legitimate sexual object... She (the mother) is awakening the her son sexual impulse and preparing its later intensity. (pp. 210-211)

The mother (or someone who replaces her), when taking care of the baby caressing and kissing him, is awakening his sexual impulse or libido. The mother (or someone who represents her) offers an endless source of sexual excitement and satisfaction of erogenous zones for her child.

And when referring to the life and death impulse presence at the child early psychic constitution, Freud postulates "that life emergence would be, then, the life continuation cause and also, at the same time, of the effort towards death. And life itself would be a conflict and a conciliation between these two trends" (1923/1996, p. 53). These two trends are the two classes of impulses the coexist since birth: the life impulse (sexual impulse or libido and self-preservation impulse) and the death impulse (destructive impulse, of domain or power desire). Life consists of conflict manifestations or the interaction between these two impulsive classes, i.e., between life impulse (Eros) and death impulse (Thanatos).

These two impulse classes are present in human psyche, but Freud notes that, at the beginning, "the libido has the mission to make the destructor instinct innocuous and performs it diverting this instinct, mainly, outside... 
with the aid of a special organic system, the muscular apparatus" (1924/1996, p. 181). The death impulse deviation to the external environment is essential for the psyche constitution. The life impulse aims to make the destructive and aggressive impulse harmless, partially directing it to outside and, partially, by mixing with it.

During the first maternal cares that the individual sexual impulse arises, Freud (1905/1996) points out:

The child lips behave as an erogenous zone, and the stimulation by the warm milk was, no doubt, the source of pleasurable sensation... Sexual activity primarily relies on one of the functions that serve for the life preservation, and only later becomes independent from them. (p. 171)

Early in life, the baby's sexual pleasure comes from the mouth-lips excitement, the tongue. At this time, sexual activity can be related to milk intake, the lips stimulation, etc..

In addition to providing that sexual pleasure, the affectionate relationship between baby and mother becomes a model for all loving relationships in the individual life. Freud declares that "the object encounter (at puberty) is, in fact, a re-encounter" (1905/1996, p. 210). This means that even after the sexual activity is separated from the nutrition act, a significant portion remains to prepare the boy to the object choice at puberty, being this object encounter a re-encounter of the old love object abandoned in remote childhood, after the Oedipus complex resolution.

From birth, the Viennese master underlines the parents' presence importance (and not only the mother) in the son psychic constitution. In relation to this presence, Freud (1914/1996) explains:

So they (the parents) are under the compulsion of assigning all perfections to the son... and hiding and forgetting all his deficiencies... He will once again really be the center and the creation essence- "His Majesty the Baby"... The child will materialize the golden dreams that parents have never realized... The parents' love, so touching and in fact so childish, is nothing more than the parents' narcissism reborn, which, transformed into love object, unmistakably revels its previous nature. (pp. 97-98)

For Freud, concomitantly to the mother presence, the father is also present since the child early psychic constitution. The child birth represents for the couple (here understood as father and mother) a revival of their own narcissism that had been long abandoned. So, mom and dad relieve the old childish narcissism with their child birth, assigning all the world perfections to this new son, and denying his faults and imperfections.

According to the Freudian metapsychology, in addition to the parents' old narcissism revival with the son birth, the self-eroticism and the narcissism deserve a brief highlight in the male sex subject psychic constitution.

In a letter to Fliess, Freud already defined the self-eroticism as "a lower sexual layer... that acts without any psychosexual objective and only requires the local sensations of satisfaction" (1986/1899, p. 331).

Six years after writing this letter, Freud writes the Three Essays on Sexuality Theory. In this brilliant book, which caused (and still causes) much criticism to psychoanalysis, Freud expresses that, in early life, "The impulse is not directed to another person; it is satisfied in the own body, it is the self-erotic" (1905/1996, p. 270). In other words, the baby presents a mode by which the sexual impulse finds satisfaction in his own body. And this mode is referred to as self-eroticism.

It is necessary to point out that, for Freud (1914/1996):

A unit comparable to ego cannot exist in the individual since the beginning; ego has to be developed. The self-erotic impulses, however, have been there since the beginning, and therefore, it is necessary that something is added to the self-eroticism — a new psychic action—in order to provoke the narcissism. (p. 84) 
Thus, the self-eroticism, i.e., the mode by which the impulse seeks satisfaction in the subject own body, is present since the beginning. Narcissism is the result of a new psychic action which would be added to self-eroticism.

Although not specified in the text "Regarding Narcissism: An Introduction" (1914) what is this psychic action, in the article "The Impulses and its Vicissitudes", Freud (1915/1996) says:

We are used to denote the ego development initial phase, during which the sexual instincts find the self-erotic satisfaction, of "narcissism"... At the very beginning of life, ego is catechized with the instincts, being, to a certain extent, able to satisfy them in ourselves. We call this condition "narcissism" condition, and this form of obtaining satisfaction, "self-erotic". (pp. 137-139)

In this text, he understands narcissism as a first way in which ego is constituted, because thanks to "his majesty, the baby" (Freud, 1914/1996, p. 84), the child's ego is organized in its early form as an ideal ego, narcissistically invested by libido and which masterpiece the boy is not willing to renounce during his childhood. Thus, the ego is a unit that does not exist since the psychic constitution beginning, needing to become, as an ideal ego, to be narcissistically invested by the parents.

It seems necessary to point out that for Freud (1923/1996), before the ideal ego resulting in narcissism, the ego is "first and foremost, a body ego; and not simply a surface entity, but it is... a projection of a surface" (p. 42). In the psychic early constitution, the newborn is provided of an ID and, then, a body ego, targeting to the establishment of an ideal ego narcissistically invested.

On the subject psychic constitution, in addition to the ideal ego presence, it is necessary to point out the role played by pre-genital organizations.

In the libidinal development level, Freud postulates that "during the early years of a child life, there are organizations in which the genital areas have hot assumed its predominant role" (1905/1996, p. 186). These organizations are defined as pre-genitals in which the impulses are partial and which objective is the satisfaction by means of the appropriate stimulation of the erogenous zone.

Freud defines the erogenous zone as "a part of the skin or mucosa where certain types of stimulation causes a pleasurable sensation of certain quality" (1905/1996, p. 187). These dominant areas are, respectively, the mouth in the oral phase and the anus in the anal phase. Still, according to Freud, "The first of these pre-genital sexual organizations is the oral, or... cannibalistic. In it, the sexual activity has not yet separated from nutrition, nor differentiated from the opposing currents inside it" (1905/1996, p. 186).

In this organization, sexual activity is related to the nutrition and erogenous dominant zone is the mouth. During this organization, the child feels pleasure sucking the mother breast. That is, at the beginning of the baby's life, the psychic activity focuses on providing satisfaction to oral zones needs, such as sucking the milk from the mother breast and subsequently sucking (somehow) another object that replaces the breast, such as the finger or pacifier. The act of sucking on the mother breast is the first activity that provides pleasure to the baby, where his lips behave as an erogenous zone. Thus, sexuality begins to manifest in the baby and after breastfeeding, when he starts sucking the breast, finger, or pacifier.

During the oral organization, Freud declares that the "Sexual target consists in the incorporation of the object, model that later will play, in the form of identification, an important psychic role" (1905/1996, p. 187). The author understands that Freud relieves in this incorporation the prototype of the first identifications of a child. 
Freud returns to the identification problems in the oral organization when publishing the "Group Psychology and Ego Analysis". In this text, Freud points out that the boy identification with his father during the phallic phase "behaves as a derivative of the first phase of libido organization, of the oral phase, in which the object that we value and for which we desire is assimilated by the ingestion in this oral or cannibalistic phase" (1921/1996, p. 115). In other words, since the oral organization, the first identification of the boy with the father figure may occur. The boy may show an interest for his father, a moment in which he conceives the father figure as his ideal.

During the oral organization, Freud also recognizes that "The boy develops an object cathexis for the mother, originally related to the mother breast, and which is the prototype of an object choice according to the anaclitic model" (1923/1996, p. 44). The boy, at the same time in which he develops the identification with the father, he also develops a cathexis of sexual object regarding the mother, and the rivalry with the father is not present at this moment, which will occur only in the infant genital organization, that is, during the phallic phase.

For Freud, the second pre-genital organization is the anal-sadistic which dominant erogenous zone is the anal. In this organization, Freud (1905/1996) says:

The intestinal contents... have for the breastfeeding other important senses. It is obviously treated as a part of his own body, representing the first "gift". When disposing of it, the little creature can express docility to the environment surrounding him, and when refusing it, his stubbornness. (p. 176)

During the anal-sadistic organization, the faeces represent the first gift that the child can give someone that he likes, demonstrating his obedience. If he denies giving the faeces, he is expressing his stubbornness.

Freud (1905/1996) explains that "the fecal mass retention, at first intentionally practiced to take advantage of the stimulation as an anal zone masturbatory... is, by the way, one of the constipation reasons, which is so frequent in neuropaths" (p.176). The fecal mass retention during childhood may be related to masturbatory stimulation of anal zone, as it can also demonstrate the pertinacity in the relationship with the people who take care of this child. And when growing, this game of retaining faeces may be symbolically present in the special scatological rituals, in ceremonial acts and similar acts which are carefully kept confidential by the neurotic individual.

Freud (1913/1996) points out that in anal-sadistic organization, "The genital zones primacy has not yet been established. On the contrary, the instinct components that dominate this pre-genital organization of sexual life are the anal-erotic and sadistic" (p. 345).

In a note added to Three Essays on Sexuality Theory, Freud (1915/1996) recognizes that, in this organization "the division into opposites that pervades the sex life has already constituted, but they still cannot be called male and female, but rather active and passive" (p. 187). In the anal-sadistic organization, the present activity is the domination impulse through the body muscles and, as a passive sexual target organ, the intestine erogenous mucosa is found. At this infantile psychosexuality constitution phase, the primacy of the genital areas is not established yet. The antithesis between male and female does not exist, but rather the opposition between active and passive.

During this pre-genital organization, the active inclination is filled by the domain common instinct that Freud calls sadism and the passive inclination is fueled by the anal eroticism. A fortification of anal eroticism allows an inclination to homosexuality in males when the genitals primacy is achieved. 
On the New Conferences, Freud (1933/1996) notes that:

The attitude towards the libido organization phases has changed a bit... Whereas, previously, it was mainly emphasized the way how each phase passed before the next phase, our attention, now, is directed to the facts that show how much of each prior phase still continues in the subsequent configurations... ( p. 102)

Namely, the predominance of one phase in relation to the other does not occur so suddenly, but gradually, since parts of the previous organization always coexist side by side the latest.

In another footnote added to Three Essays on Sexuality Theorys, Freud (1905/1996) revels that "after the two pre-genital organizations, there is a third phase in child development: This, that already deserves the name of genital... only knows one type of genitalia: the male. For this reason I called it the organization phallic phase" (p. 188). The third organization described by Freud is the infant genital organization, in which, due to the phallus primacy, is also called phallic phase. In this phase, culminate the Oedipus complex and the castration complex.

\section{The Phallic Phase: A Brief Description}

For the Viennese master:

The main characteristic of this "infant genital organization" is its difference from the adult final genital organization. It consists in the fact that, for both sexes, only one genital organ is considered, namely, the male. What is present, therefore, is not a priority of the genitals, but the phallus primacy. (Freud, 1923/1996, p. 158)

At this phase, both the boys and the girls only recognize one genital organ: the male. In the case of the boy, his genital organ attracts his interest; since he wants to see this part of the body in other people, in order to compare it with the part of his body. In the course of his sexual researches, he comes across with the discovery that the penis is not a common possession to all people. Therefore, in the infant genital organization, the phallus primacy is present, that is, the opposition of having the phallus or being castrated. This opposition is related to the Oedipus complex development and, concomitantly, the castration complex, because it is in the phallic phase that the Oedipus complex (articulated with the castration complex) reaches its apogee.

\section{The Male Oedipus Complex}

About the male Oedipus complex, Freud (1923/1996) states that:

One gets the impression that in any form the simple Oedipus complex is the... most common form, but it rather represents a simplification... A deeper study generally revels the most complete Oedipus complex, which is duplicitous, positive and negative... In my opinion, it is advisable... and very especially regarding the neurotic, to assume the existence of the complete Oedipus complex. (pp. 45-46)

During the infant genital organization (or phallic phase), the boy sexual desire with regard to the mother acquires a greater intensity and the father figure becomes an obstacle, a rival to the realization of his incestuous desire. On the other hand, the identification with the father figure makes room for rivalry and hostility, culminating in a parricide desire, of getting rid of him with the objective of occupying his place on his mother side, thus originating the Oedipus complex. But during the infant genital organization, there is not only the positive Oedipus complex development, but concomitantly to the positive complex, there is the negative Oedipus complex. This means that for Freud, not only the simple positive Oedipus complex occurs in the case of the boy; but a more complete Oedipus complex, which is positive and negative, due to the bisexuality originally present in the child. 
So, the boy does not present an ambivalent attitude towards his father and an object relation of unique affectionate type with his mother. This boy can also behave like a girl and show a female affectionate attitude towards the father and a corresponding jealousy and hostility towards the mother. But the author highlights that it is the castration complex that puts an end to the male Oedipus complex.

\section{The Castration Complex}

In the text "The Infant Genital Organization", Freud (1923/1996) exposes that "the castration complex meaning can only be properly appreciated if its origin in the phallic primacy is also taken into account" (pp. 159-160). It is in this text that it is assigned to the castration complex its fundamental place in the Freudian theory set for the infant sexuality evolution, being articulated to the Oedipus complex and the phallic phase. Therefore, the castration complex presents a close relationship with the Oedipus complex and, mainly, with the interdiction function of the boy incestuous and parricide desires towards the parents.

Freud (1923/1996) asserts that during the infant genital organization, "the boy... notices the distinction between men and women, but, at first, he has no occasion to link it to a difference in his genitals" (p. 160). The boy assumes that all living beings and the inanimate things that surround him have a genital organ like his. This organ occupies his interest during his sexual curiosities, because he wants to see it in other people also.

During the sexual researches, when observing the genitals of his sister of little friend, the boy discovers that the penis is not present in all the people who surround him, being this lack understood as a result of castration. At this moment, the boy faces the task of reaching an agreement with castration regarding himself, since the loss of his penis becomes imaginable. Consequently, the fantasy of losing his penis gains strength every time he recalls the female genitals appearance, because the finding by the boy of the anatomical distinction of sexes is fundamental to the emergence of the castration complex.

\section{The Interlacing Between Oedipus Complex and the Castration Complex: A Brief Discussion on the Results of the Oedipal Complex Dissolution}

About the Oedipus complex and its articulation with the castration complex, Freud (1924/1996) states that:

If the satisfaction of love in the Oedipus complex field should cost the penis to the child, it is bound to arise a conflict between his narcissistic interest in that part of his body and the libidinal cathexis of his parental objects. In this conflict, usually the first of this forces triumphs: The child ego turns its back to the Oedipus complex... The Oedipus complex destruction is caused by the castration threat. (p. 196)

In the case of the boy, the castration anxiety falls upon the complete Oedipus complex, putting an end to it. The boy, in order to preserve his sexual organ, gives up the pleasure he was seeking in his mother.

About the end of the Oedipus complex, Freud (1924/1996) declares that "He sees no reason to deny the repression name to the ego's distance from the Oedipus complex, although the subsequent repressions occur mostly with the superego participation..." (p. 197). In the case of the boy, due to the castration anxiety, the ego uses the infant sexuality repression. When repressing the Oedipus complex, the boy abdicates the libidinal cathexis that was deposited on the parental figures. These cathexis are abandoned and its objects are incorporated to the ego, constituting the superego. In this way, in the closure of the male Oedipus complex, there is a repression of incestuous and parricide desires. If this fails, psychopathological manifestations may occur in the late childhood or in a later moment in the adult life of this individual. 
Freud (1933/1996) explains that:

Abandoning the Oedipus complex, a child must... renounce the intense object cathexis that he deposited on his
parents, and it is as a compensation for this loss of objects that there is such great intensification of the identifications with
his parents, which probably have been present in his ego for a long time. (p. 69)

In the case of the boy, the object cathexis is abandoned and replaced by identifications, which were already present in his ego during the pre-genitals organizations. Therefore, with the end of the phallic phase, there is an intensification of the boy's identification with the father figure. And the identifications, having as a model the parental figures, are repeated, later, in the individual life.

At the end of the infant genital organization, Freud (1933/1996) also expresses that "The Oedipus complex is abandoned on the boy, being repressed, destroyed, and a severe superego is installed is a heir" (p. 129). In the boy, in addition to a possible paternal identification (or maternal) after the repression of his Oedipus complex, the superego and the ego ideal are the inheritors of this complex.

When referring to the ego ideal formation, Freud (1914/1996) states:

For the ego, the formation of an ideal would be a conditioning factor of repression... What the subject projects towards himself as being his ideal (of ego) is the replacement for the narcissism lost in his childhood in which he was his own ideal... The ego development consists in the removal of his primary narcissism... This removal is caused by the libido displacement towards an externally imposed ego ideal. (pp. 100-102)

Thus, during the pre-genital and infant genital organization, there is a narcissistic invested ideal ego. Due to the castration anxiety during the phallic phase, there is the infantile sexuality and ideal ego repression, which hers are, as stated in the previous paragraph, the superego and the ideal ego. This ideal ego is the narcissism replacement lost in childhood.

When writing The Ego and the Id, Freud stresses that the differentiation within the ego "can be called 'ego ideal' or 'superego"' (1923/1996, p. 43). At this time, Freud uses both concepts interchangeably, but it is only in the New Conferences that he elaborates a differentiation between superego and ideal ego. In these conferences, Freud (1933/1996) declares that superego is:

The ego ideal vehicle, by which the ego is evaluated, that stimulates it and which requirements for perfection are always greater than what he strives to accomplish... This ego ideal is the precipitate of the parents old image, the admiration expression by the perfection that the child so attributed to them. (p. 70)

It is understood that Freud imputes to the superego a function of being the ego ideal vehicle responsible for the perfection pursuit, being the superego responsible for the ego ideal maintenance. Its functions are the self-observation, the consciousness, and the maintenance of this ideal. On the other hand, the ego ideal has the function to stimulate the ego to achieve perfection and serve as an instrument through which ego evaluates itself.

On superego formation, Freud (1924/1996) considers that "The father or both parents authority is introjected in the ego, and there forms the superego core, which assumes the father severity and perpetuates his prohibition against incest, thus defeating the ego of libidinal cathexis return" (p. 196). Superego retains the strength, severity, and the inclination to punish that are inherited from parents. This psychic instance protects the ego against to the incestuous desires return.

For Freud (1933/1996):

The child superego is, in fact, built not according to the his parents' model, but his parents' superego... It becomes a 
tradition vehicle and all of long lasting value judgments that this way were transmitted from generation to generation. (p. 69)

Then, the superego of a boy is above all, a psychic instance where the values that go beyond his parents' superego are present, since the values and judgments are transmitted from generation to generation.

After the latency phase end (where we found the superego formation according to the Freudian conception), there begins the adult genital organization. In this organization, the "(Oedipus) complex is unconsciously revived and involved in new modifications" (Freud, 1924/1996, p. 263). At puberty, man revives in his unconscious the old Oedipal complex repressed in his early childhood. In this organization, the sexual impulses are put in the reproduction service. During puberty that one can establish a clear separation between the male and female characters, establishing the genital areas primacy that was not possible in the infant genital organization. At this phase, the man can present an object choice of anaclitic or connection object type, since it is during puberty when the adult sexual life final configuration occurs, when the object encounter is consummated, which path had been prepared from the most remote childhood.

\section{Conclusion}

Throughout this paper, the core concepts linked to psychic constitution of male subject in Freudian theory were crossed, but it is necessary to highlight that due to the Oedipal complex articulation with the castration complex, each subject may present three possible exits for his infantile sexuality, i.e., three psychic destinations: neurosis, psychosis, and perversion. While that, for Freud (1924), in neurosis there is the castration recognition, in psychosis occurs the refusal of it, being the delirium a bridge to the reality that was excluded. And in perversions, there is a recognition, and the castration refusal, being the fetishism of its prototype.

Therefore, before making a diagnosis of each clinical case, the psychotherapist is entitled to recognize his patient in the symptom singularity, listening to him in his libidinal and identification story. It is from his listening that the concepts listed above will create liveliness in the clinical practice, allowing the construction of a clinical listening.

\section{References}

Freud, S. (1996). Project for a scientific psychology (J. Salomão, translator). In the Brazilian standard edition of the complete psychological works of Sigmund Freud (Vol. I, pp. 335-411). Rio de Janeiro: Imago. (Original published in 1950).

Freud, S. (1996). The dreams interpretation. (J. Salomão, translator). In the Brazilian standard edition of the complete psychological works of Sigmund Freud (Vol. V, pp. 541-655). Rio de Janeiro: Imago. (Original published in 1900).

Freud, S. (1996). Three essays on the sexuality theory. (J. Salomão, translator). In the Brazilian standard edition of the complete psychological works of Sigmund Freud (Vol. VII, pp. 117-218). Rio de Janeiro: Imago. (Original published in 1905).

Freud, S. (1996). Anal character and eroticism. (J. Salomão, translator). In the Brazilian standard edition of the complete psychological works of Sigmund Freud (Vol. IX, pp. 159-169). Rio de Janeiro: Imago. (Original published in 1908).

Freud, S. (1996). On the sexual theories of children. (J. Salomão, translator). In the Brazilian standard edition of the complete psychological works of Sigmund Freud (Vol. IX, pp. 191-208). Rio de Janeiro: Imago. (Original published in 1908).

Freud, S. (1996). Formulations on the two principles of mental functioning. In the Brazilian standard edition of the complete psychological works of Sigmund Freud (Vol. XII, pp. 231-243). Rio de Janeiro: Imago. (Original published in 1911).

Freud, S. (1996). Contributions to a debate on masturbation. In the Brazilian standard edition of the complete psychological works of Sigmund Freud (Vol. XII, pp. 257-272). Rio de Janeiro: Imago. (Original published in 1912).

Freud, S. (1996). About narcissism: An introduction. In the Brazilian standard edition of the complete psychological works of Sigmund Freud (Vol. XIV, pp. 75-110). Rio de Janeiro: Imago. (Original published in 1914).

Freud, S. (1996). The instincts and its vicissitudes. In the Brazilian standard edition of the complete psychological works of Sigmund Freud (Vol. XIV, pp. 115-144). Rio de Janeiro: Imago. (Original published in 1915). 
Freud, S. (1996). Repression. In the Brazilian standard edition of the complete psychological works of Sigmund Freud (Vol. XIV, pp. 115-144). Rio de Janeiro: Imago. (Original published in 1915).

Freud, S. (1996). XIX Conference-Resistance and repression. In the Brazilian standard edition of the complete psychological works of Sigmund Freud (Vol. XVI, pp. 293-308). Rio de Janeiro: Imago. (Original published in 1917).

Freud, S. (1996). Group psychology and the ego analysis. In the Brazilian standard edition of the complete psychological works of Sigmund Freud (Vol. XVIII, pp. 77-154). Rio de Janeiro: Imago. (Original published in 1921).

Freud, S. (1996). The ego and the Id. In the Brazilian standard edition of the complete psychological works of Sigmund Freud (Vol. XIX, pp. 13-80). Rio de Janeiro: Imago. (Original published in 1923).

Freud, S. (1996). Infant genital organization: An interpolation of sexuality theory. In the Brazilian standard edition of the complete psychological works of Sigmund Freud (Vol. XIX, pp. 153-162). Rio de Janeiro: Imago. (Original published in 1923).

Freud, S. (1996). Masochism economic problem. In the Brazilian standard edition of the complete psychological works of Sigmund Freud (Vol. XIX, pp. 173-188). Rio de Janeiro: Imago. (Original published in 1924).

Freud, S. (1996). Dissolution of oedipus complex. In the Brazilian standard edition of the complete psychological works of Sigmund Freud (Vol. XIX, pp. 189-200). Rio de Janeiro: Imago. (Original published in 1924).

Freud, S. (1996). Neurosis and psychosis. In the Brazilian standard edition of the complete psychological works of Sigmund Freud (Vol. XIX, pp. 163-172). Rio de Janeiro: Imago. (Original published in 1924).

Freud, S. (1996). Some psychic consequences of anatomical distinction between the sexes. In the Brazilian standard edition of the complete psychological works of Sigmund Freud (Vol. XIX, pp. 271-286). Rio de Janeiro: Imago. (Original published in 1925).

Freud, S. (1996). Inhibitions, symptoms and anxiety. In the Brazilian standard edition of the complete psychological works of Sigmund Freud (Vol. XX, pp. 79-168). Rio de Janeiro: Imago. (Original published in 1926).

Freud, S. (1996). XXXI Conference-The dissection of psychic personality. In the Brazilian standard edition of the complete psychological works of Sigmund Freud (Vol. XX, pp. 63-84). Rio de Janeiro: Imago. (Original published in 1933).

Freud, S. (1996). XXXII Conference-Anxiety and instinctive life. In the Brazilian standard edition of the complete psychological works of Sigmund Freud (Vol. XX, pp. 85-112). Rio de Janeiro: Imago. (Original published in 1933).

Freud, S. (1996). Psychoanalysis outline. In the Brazilian standard edition of the complete psychological works of Sigmund Freud (vol. XXIII, pp. 151-208). Rio de Janeiro: Imago. (Original published in 1940).

Masson, J. M. (1986). The complete correspondence of Sigmund Freud to Wilhelm Fliess 1887-1904. Rio de Janeiro: Imago. 